\title{
Sexual Transmission of Strongyloidiasis: A Case Report
}

\author{
Patrice Bourée ${ }^{1,2^{*}(\mathbb{C}}$, Dorsaf Slama ${ }^{2}$, Rafael Usubillaga $^{2}$, Dominique Salmon $^{2}$ \\ ${ }^{1}$ Alfred Fournier Institute, Paris, France \\ ${ }^{2}$ Department of Infectious Diseases, Hôtel-Dieu Hospital, Paris, France
}

\begin{abstract}
Some parasites, such as Trichomonas vaginalis or Sarcoptes scabiei, are sexually transmitted. However, sexual transmission of most intestinal parasites is very rare. The present study reports a case of homosexual man infected with HIV who was found to be a carrier of Strongyloides stercoralis, even though he had never traveled to the tropics. However, he had repeated sexual relations with many partners, some of whom were from endemic areas. Sexual transmission of Strongyloides stercoralis and amoebiasis due to Entamoeba histolytica is rare but has already been found in the population at risk. Therefore, this parasitosis should be sought in HIV patients complaining of digestive disorders.

Keywords: Strongyloides stercoralis, sexual transmission, Entamoeba histolytica, Ivermectin
\end{abstract}

Received: October 19, 2020, Accepted: December 10, 2020, ePublished: January 1, 2021

\section{Introduction}

A number of parasitic diseases can be transmitted sexually, such as trichomoniasis, amoebiasis, or scabies. However, other intestinal parasites can also be transmitted in this way. Strongyloides stercoralis (threadworm) is a tropical intestinal helminth species that can persist for a long time in the host organism to complete its life cycle and cause serious problems in immunocompromised patients (1). Usually, the person carrying these parasites eliminates, with his stool, larvae which will moult in a few days in nature to become infesting forms. These larvae stay on the ground for a long time and penetrate through the skin of people walking barefoot in muddy ground (2). The following observation demonstrates another way of transmission of this parasite.

\section{Case Presentation}

A 49-year-old homosexual man presented with a complaint of oral yeast infection. Clinical and biological examinations of this patient confirmed HIV infection, with a CD4 count of 620 cells $/ \mathrm{mm}^{3}$ and a viral load of 318000 copies $/ \mathrm{mL}$, without other biological disturbances. The patient was therefore treated with tritherapy and the viral load dropped to 19000 copies/mL in 2 months and became undetectable in 3 months. After 18 months, the CD4 count rose to $828 / \mathrm{mm}^{3}$ and then to 1033 cells/ $\mathrm{mm}^{3}$ after 2 years, with an undetectable viral load. The patient was still under treatment, but 5 years later, he referred with complaints of gastrointestinal symptoms such as nausea and frequent diarrhea, with weight loss and tachycardia. The WBC count was 12300 cells $/ \mathrm{mm}^{3}$, including 520 eosinophils $/ \mathrm{mm}^{3}$. Larvae of Strongyloides stercoralis were detected in several parasitological stool examinations (Figure 1). This is surprising because this patient had no history of travel to a tropical area, but he had multiple sexual partners from tropical countries.

After treatment with ivermectin, symptoms disappeared and the eosinophils count rose to $4400 / \mathrm{mm}^{3}$ before returning to a normal level one month later. A year later, following intravenous drug injection, Strongyloides stercoralis larvae were also detected in a new stool examination, which required a new course of ivermectin. Then, the other follow-up parasitological examinations of stool remained negative.

\section{Discussion}

The presence of this tropical parasite is unusual in a patient who has never left Europe. The usual transcutaneous contamination in external environment was not considered, but it could be explained by a sexual transmission during frequent sexual relations of this immunocompromised patient with partners originating from endemic areas, such as Brazil, where the enteric parasites are prevalent in AIDS patients (3) (Table 1). Sexual transmission of intestinal parasites, especially amoebae, was noticed in 1967 in Manhattan (USA) in homosexual people who had no history of travel but had homosexual contacts with people arriving from India (4). Other intestinal parasites have also been found to be transmitted through sexual contact, such as Entamoeba histolytica, Entamoeba coli (5-7), Enterobius vermicularis (8), Giardia intestinalis (9), or Cryptosporidium (10), 


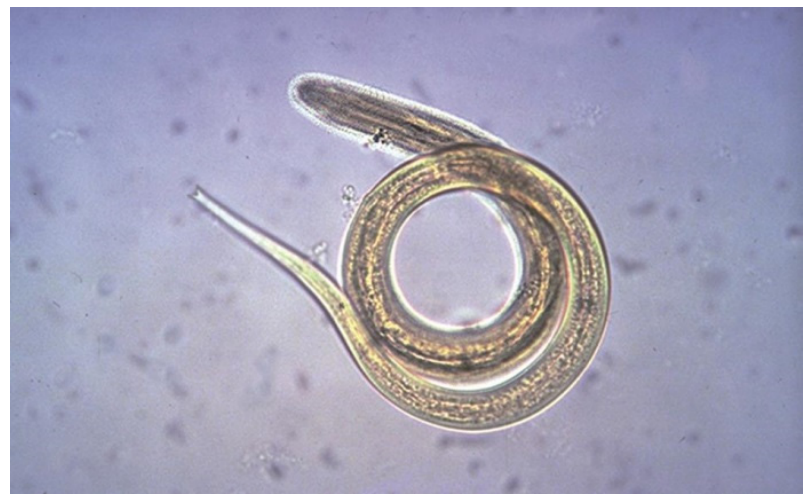

Figure 1. Larva of Strongyloides Stercoralis

especially in homosexual people infected with HIV (11). Similarly, Strongyloides stercoralis larvae were found in a patient who had never traveled but had sexual relations with twelve partners, two of whom were carriers of Strongyloides stercoralis (12).

It is interesting to note that in a study on 163 men (average age 30 years) which was carried out in New York in a center for sexually transmitted diseases, the parasitic infection was more prevalent in homosexual people than in heterosexual people (Table 2). Oral-anal sex is an important risk factor for helminthic infections (13), as confirmed by a study conducted in Canada (14) (Table 3 ), with the same clinical consequences (abdominal pain, diarrhea, and bloating) as during usual transcutaneous contamination (15). In addition, Strongyloides stercoralis larvae were found in semen (16). Direct person to person transmission of Strongyloides stercoralis has already been reported (17), but it is very rare, as shown in a study on 24 families where the husbands had been infected with Strongyloides stercoralis for many years but their wives were not infected (18).

A study carried out in San Francisco on 500 homosexual people found that oral-anal contact contributes to the direct transmission of certain intestinal parasites (Table 4), as well as the number of sexual partners (9) (Table 5). Therefore, the sexual transmission of amoeba has been reported to cause lesions in the penis (19) in addition to colitis and liver abscesses $(20,21)$. Understanding the etiology of parasitic diseases in male homosexuals with digestive disorders is of great importance as it determines the choice of effective treatment. Prevention is difficult because regular stool examinations should be performed in all people infected with HIV who have sexual relations with people from endemic areas (22).

\section{Conclusion}

In conclusion, it is important to investigate parasites in homosexual men with complaints of gastrointestinal symptoms, even without a history of travel to endemic areas, especially Strongyloides stercoralis which must be included in the list of sexually transmitted parasites.
Therefore, stool examinations are needed to be done in homosexual people native to tropical countries.

\section{Conflict of Interests}

The authors declare that they have no competing interests.

\section{Informed Consent}

Written informed consent was obtained from the patient for publication of this report.

Table 1. Enteric Parasites in AIDS Patients in Rio de Janeiro (3)

\begin{tabular}{lc}
\hline Parasites & $\%$ \\
\hline Cryptosporidium, Entamoeba coli, Endolimax nanus & 18.2 \\
Strongyloides stercoralis, Giardia intestinalis & 15.2 \\
Entamoeba histolytica & 13.1 \\
Ascaris lumbricoides & 11.1 \\
Isospora belli & 10.1 \\
\hline
\end{tabular}

Table 2. Frequency of Infection with Intestinal Parasites in Men According to their Sexual Orientation in New York (13)

\begin{tabular}{lccc}
\hline Parasites & $\begin{array}{c}\text { Heterosexual } \\
(\mathbf{n}=\mathbf{6 4})\end{array}$ & $\begin{array}{c}\text { Bisexual } \\
(\mathbf{n = 4 7 )}\end{array}$ & $\begin{array}{c}\text { Homosexual } \\
(\mathbf{n}=\mathbf{5 1})\end{array}$ \\
\hline Entamoeba histolytica & 0 & $2,3 \%$ & $19.6 \%$ \\
Giardia intestinalis & 0 & $4,2 \%$ & $3.9 \%$ \\
Entamoeba coli & $9.4 \%$ & $10.4 \%$ & $23.5 \%$ \\
Strongyloides stercoralis & $1.3 \%$ & 0 & $3.9 \%$ \\
Trichuris trichiura & 0 & 0 & $2.0 \%$ \\
\hline
\end{tabular}

Table 3. Prevalence of Parasite Infestation in Heterosexual and Homosexual Men in Canada (14)

\begin{tabular}{lcc}
\hline Parasites & $\begin{array}{c}\text { Heterosexuals } \\
(\mathbf{n = 1 0 0})\end{array}$ & $\begin{array}{c}\text { Homosexuals } \\
(\mathbf{n}=\mathbf{2 0 0})\end{array}$ \\
\hline Entamoeba histolytica & $1 \%$ & $27.9 \%$ \\
Giardia intestinalis & $3 \%$ & $13 \%$ \\
Ascaris lumbricoides & 0 & $0.5 \%$ \\
\hline
\end{tabular}

Table 4. Correlation Between Frequency of Oral-Anal Contacts and Parasitic Infection in 500 Homosexual Men in San Francisco (9)

\begin{tabular}{lcccc}
\hline \multirow{2}{*}{ Parasite } & \multicolumn{4}{c}{ Frequency of Oral-Anal Contacts } \\
\cline { 2 - 5 } & None & Episodic & Sometimes & Frequent \\
\hline Entamoeba intestinalis & $10.6 \%$ & $32.4 \%$ & $42.7 \%$ & $43.2 \%$ \\
Giardia intestinalis & $1.6 \%$ & $6.2 \%$ & $4.9 \%$ & $21.8 \%$ \\
Various protozoa & $12.5 \%$ & $66.7 \%$ & $64.6 \%$ & $73.0 \%$ \\
\hline
\end{tabular}

Table 5. Correlation Between Parasitic Infection and the Number of Sexual Partners in 500 Homosexual Men in San Francisco (9)

\begin{tabular}{lcccc}
\hline \multirow{2}{*}{ Parasites } & \multicolumn{4}{c}{ Number of Partners Per Year } \\
\cline { 2 - 5 } & $\mathbf{1 - 5}$ & $\mathbf{6 - 2 4}$ & $\mathbf{2 5 - 9 9}$ & $>\mathbf{1 0 0}$ \\
\hline Entamoeba histolytica & $13.5 \%$ & $25.1 \%$ & $36.7 \%$ & $40.8 \%$ \\
Giardia intestinalis & $4.5 \%$ & $4.7 \%$ & $6.3 \%$ & $8.2 \%$ \\
Various protozoa & $46.1 \%$ & $52.4 \%$ & $63.3 \%$ & $69.4 \%$ \\
\hline
\end{tabular}




\section{References}

1. Purtilo DT, Meyers WM, Connor DH. Fatal strongyloidiasis in immunosuppressed patients. Am J Med. 1974;56(4):488493. doi:10.1016/0002-9343(74)90481-1

2. Nicolas X, Chevalier B, Klotz F. Anguillule et anguillulose. EMC - Maladies Infectieuses. 2005;2(1):42-58. doi:10.1016/j.emcmi.2004.07.004

3. Moura H, Fernandes O, Viola JP, Silva SP, Passos RH, Lima DB. Enteric parasites and HIV infection: occurrence in AIDS patients in Rio de Janeiro, Brazil. Mem Inst Oswaldo Cruz. 1989;84(4):527-533. doi:10.1590/s007402761989000400010

4. Most H. Manhattan: "a tropic isle"? Am J Trop Med Hyg. 1968;17(3):333-354. doi:10.4269/ajtmh.1968.17.333

5. Pakianathan MR, McMillan A. Intestinal protozoa in homosexual men in Edinburgh. Int J STD AIDS. 1999;10(12):780-784. doi:10.1258/0956462991913547

6. Wexner SD. Sexually transmitted diseases of the colon, rectum, and anus. The challenge of the nineties. Dis Colon Rectum. 1990;33(12):1048-1062. doi:10.1007/bf02139224

7. Levine GI. Sexually transmitted parasitic diseases. Prim Care. 1991;18(1):101-128.

8. Abdolrasouli A, Hart J. Oral-anal intercourse and sexual transmission of Enterobius vermicularis; do we need to screen for other intestinal parasites? Int J STD AIDS. 2009;20(10):739. doi:10.1258/ijsa.2009.009263

9. Markell EK, Havens RF, Kuritsubo RA, Wingerd J. Intestinal protozoa in homosexual men of the San Francisco Bay area: prevalence and correlates of infection. Am J Trop Med Hyg. 1984;33(2):239-245. doi:10.4269/ajtmh.1984.33.239

10. Abdolrasouli A, McMillan A, Ackers JP. Sexual transmission of intestinal parasites in men who have sex with men. Sex Health. 2009;6(3):185-194. doi:10.1071/sh08084

11. Stark D, Fotedar R, van Hal S, et al. Prevalence of enteric protozoa in human immunodeficiency virus (HIV)-positive and HIV-negative men who have sex with men from Sydney, Australia. Am J Trop Med Hyg. 2007;76(3):549-552.

12. Sorvillo F, Mori K, Sewake W, Fishman L. Sexual transmission of Strongyloides stercoralis among homosexual men. Br J Vener Dis. 1983;59(5):342. doi:10.1136/ sti.59.5.342

13. Phillips SC, Mildvan D, William DC, Gelb AM, White MC. Sexual transmission of enteric protozoa and helminths in a venereal-disease-clinic population. $\mathrm{N}$ Engl J Med. 1981;305(11):603-606. doi:10.1056/nejm198109103051102

14. Keystone JS, Keystone DL, Proctor EM. Intestinal parasitic infections in homosexual men: prevalence, symptoms and factors in transmission. Can Med Assoc J. 1980;123(6):512514.

15. Bourée P, Taugourdeau A, Barthelémy $M$, PequignotRicome H, Passeron J, Bouvier JB. [Strongyloidiasis: a clinical, biological and epidemiological study of 350 cases (author's transl)]. Nouv Presse Med. 1981;10(9):679-681. [French].

16. Agbo K, Deniau M. [Anguillospermia resistant to treatment. Apropos of a case diagnosed in Togo]. Bull Soc Pathol Exot Filiales. 1987;80(2):271-273. [French].

17. Czachor JS, Jonas AP. Transmission of Strongyloides steracolis person to person. J Travel Med. 2000;7(4):211212. doi: $10.2310 / 7060.2000 .00063$

18. Grove DI. Strongyloidiasis: is it transmitted from husband to wife? Br J Vener Dis. 1982;58(4):271-272. doi:10.1136/ sti.58.4.271

19. Abdolrasouli A, de Vries HJ, Hemmati Y, Roushan A, Hart J, Waugh MA. Sexually transmitted penile amoebiasis in Iran: a case series. Sex Transm Infect. 2012;88(8):585-588. doi:10.1136/sextrans-2012-050577

20. Stark D, van Hal SJ, Matthews G, Harkness J, Marriott D. Invasive amebiasis in men who have sex with men, Australia. Emerg Infect Dis. 2008;14(7):1141-1143. doi:10.3201/eid1407.080017

21. Thompson JE Jr, Freischlag J, Thomas DS. Amebic liver abscess in a homosexual man. Sex Transm Dis. 1983;10(3):153-155. doi:10.1097/00007435-19830700000013

22. Requena-Méndez A, Buonfrate D, Gomez-Junyent J, Zammarchi L, Bisoffi Z, Muñoz J. Evidence-based guidelines for screening and management of strongyloidiasis in nonendemic countries. Am J Trop Med Hyg. 2017;97(3):645652. doi:10.4269/ajtmh.16-0923 original work is properly cited. 